\title{
Pencatatan Pernikahan Perspektif Hukum Islam dan Undang-Undang Nomor 1 Tahun 1974
}

\author{
Abu Yazid Adnan Quthny \\ Universitas Islam Zainul Hasan Genggong Probolinggo \\ J1. Raya Panglima Sudirman No.360, Semampir, Kraksaan, Probolinggo, Jawa Timur, Indonesia 67282 \\ Ahmad Muzakki \\ Universitas Islam Zainul Hasan Genggong Probolinggo \\ Jl. Raya Panglima Sudirman No.360, Semampir, Kraksaan, Probolinggo, Jawa Timur, Indonesia 67282 \\ muzakkipasca@gmail.com

\section{Zainuddin} \\ Universitas Ibrahimy Sukorejo Situbondo \\ Sukorejo, Sumberejo, Kec. Banyuputih, Kabupaten Situbondo, Jawa Timur 68374 \\ zainuddin.haris9@gmail.com
}

\begin{abstract}
The main issues that are the focus of discussion in this journal article are related to the provisions of marriage registration according to Law Number 1 of 1974 and the law of marriage registration according to Islamic law. This study aims to determine the provisions of marriage registration according to Law No. 1 of 1974. In addition, the author wants to explain the views of Fuqoha`and Muslim scholars regarding the law of marriage registration. After conducting the discussion, it can be concluded that the Law of the Republic of Indonesia Number 1 of 1974 in Article 2 explains that the validity of marriage must be carried out according to each belief and each marriage must be recorded according to government regulations. Then related to the views of the fuqoha regarding marriage registration, they explained that the obligation to register marriages set by the government does not conflict with Islamic law because it is in accordance with the law of marriage. With the registration of marriages, in addition to realizing social order in marriage, each man and woman who are married have authentic evidence as husband and wife. Thus, the marriage has legal certainty. However, if there is a marriage that is not registered, then it is still religiously valid as long as the conditions and pillars are met.
\end{abstract}

Keywords: Marriage Registration, Islamic Law, Fiqh

\begin{abstract}
Abstrak
Pokok permasalahan yang menjadi fokus pembahasan dalam artikel jurnal ini adalah terkait ketentuan pencatatan nikah menurut UU Nomor 1 Tahun 1974 dan hukum pencatatan nikah menurut hukum Islam. Penelitian ini bertujuan untuk mengetahui ketentuan pencatatan nikah menurut UU Nomor 1 Tahun 1974. Selain itu penulis ingin menjelaskan pandangan-pandangan Fuqoha' dan para cendikiawan muslim tentang hukum pencatatan nikah. Setelah melakukan pembahasan, dapat disimpulkan bahwa UndangUndang Republik Indonesia Nomor 1 tahun 1974 pada Pasal 2 menjelaskan bahwa sahnya pernikahan harus dilakukan sesuai keyakinan masing-masing dan tiap-tiap perkawinan harus dicatat sesuai peraturan pemerintah. Kemudian berkaitan dengan pandangan fuqoha tentang pencatatan nikah ini, mereka menjelaskan bahwa kewajiban pencatatan pernikahan yang ditetapkan oleh pemerintah tidak bertentangan dengan syariat Islam karena sesuai dengan disyariatkannya pernikahan. Dengan pencatatan nikah, di samping akan terwujud ketertiban perkawinan masyarakat, juga bagi masing-masing laki-laki dan perempuan yang sudah terikat pernikahan memiliki bukti otentik sebagai pasangan suami isteri. Dengan demikian, pernikahannya memiliki kepastian hukum. Namun jika ada pernikahan yang tidak dicatatkan, maka secara agama tetap sah selama syarat dan rukunnya terpenuhi.
\end{abstract}

Kata kunci : Pencatatan Nikah, Hukum Islam, Fiqh

https://ejournal.unzah.ac.id/index.php/assyariah 


\section{PENDAHULUAN}

Indonesia bukan negara Islam, tapi negara yang mayoritas masyarakatnya adalah muslim. Hukum-hukum yang diterapkan adalah hukum-hukum peninggalan belanda, yaitu KUHP, KUHPER, RBG, dan HIR. Selain itu, ada juga aturan-aturan yang dibuat khusus untuk umat muslim berkenaan dengan hukum perdata yang meliputi perkawinan, wasiat, waris, wakaf dan penyelesaian sengketa ekonomi syariah. Semua itu diatur di dalam Kompilasi Hukum Islam dan Undang-Undang Nomor 1 Tahun 1974 tentang perkawinan.

Aturan-aturan yang ada di Kompilasi Hukum Islam dan Undang-Undang perkawinan tidak semuanya sama dengan ketentuan yang ada di dalam fiqh. Misalnya dalam persoalan pernikahan. Dalam pasal 5 dan 6 Kompilasi Hukum Islam negara mengharuskan pernikahan dicatat dan dilangsungkan dihadapan dan di bawah pengawasan pegawai pencatat nikah.

Agar lebih falid, penulis paparkan pasal 5 dan 6 beserta ayat-ayatnya. ${ }^{1}$ Pada pasal 5 ayat a dijelaskan bahwa agar terjamin ketertiban perkawinan bagi masyarakat islam, setiap perkawinan harus dicatat. Kemudian pada ayat $b$ diatur bahwa pencatatan perkawinan tersebut, pada ayat (a) dilakukan oleh pegawai pencatat nikah sebagaimana di atur dalam undang-undang nomor 22 Tahun 1946 Undang-Undang Nomor 32 Tahun 1954. Selanjutnya pada pasal 6 ada dua ayat diatur bahwa untuk memenuhi ketentuan dalam pasal 5, setiap perkawinan harus dilangsungkan dihadapan dan di bawah pengawasan pegawai pencatat nikah. Ayat selanjutnya menjelaskan bahwa perkawinan yang dilakukan diluar pengawasan pegawai pencatat nikah tidak mempunyai kekuatan hukum.

Dua pasal ini tentunya memberatkan istri yang dinikah siri ketika suaminya tidak mau melakukan kewajibannya. Karena ketika mau melaporkan suaminya ke pengadilan tidak bisa diterima dengan alasan pernikahannya tidak mempunyai kekuatan hukum. Begitu pula ketika istri menuntut biaya hidupnya. Hal ini sebagaimana diungkapkan oleh mantan ibu Negara Sinta Nuriyah Wahid yang meminta kepada perempuan Indonesia untuk menolak dinikahi secara siri, karena tidak ada perlindungan hukum bagi perempuan dalam pernikahan yang tidak diakui negara.

\footnotetext{
${ }^{1}$ Zainuddin Ali, Hukum Perdata Islam Di Indonesia, Grafika, Jakarta, 2007, 27.
} 
Masalah lain yang akan timbul akibat pernikahan yang tidak dicatatkan di KUA adalah ketika akan membuat akte kelahiran. Tentunya di dalam aktenya tidak akan ada penasaban kepada ayahnya. Di dalam akte hanya dinasabkan kepada ibunya. Selain itu, banyak persoalan administrasi yang tidak dapat di dapat diselesaikan akibat tidak adanya akte kelahiran dan surat nikah.

Dari satu sisi nikah sirri, oleh sebagian kalangan dianggap sesuai dengan fiqh karena tidak ada persayaratan pencatatan nikah di dalam kitab-kitab fiqh, misalnya keterangan yang terdapat di dalam kitab Fathul Muin, fathul Qorib dan Fathul Wahab. ${ }^{2}$ Akan tetapi ketika diterapkan akan menimbulkan masalah-masalah sebagaimana yang telah peneliti sebutkan di atas. Dan pernikahan siri tidak diakui oleh Negara.

Tentunya perbedaan aturan fiqh dan kompilasi hukum islam ini perlu dicarikan solusi yang terbaik sehingga pernikahan bisa berjalan dengan lancar tanpa melanggar norma-norma fiqh dan aturan Negara yang telah tertuang di dalam kompilasi hukum islam. Oleh karena itu, peneliti menganggap perlu untuk membahas peraturan tentang pencatatan nikah serta pandangan ulama tentang pencatatan nikah dalam perkawinan.

Berdasarkan latar belakang di atas, maka pokok permasalahan yang menjadi fokus pembahasan dalam penelitian ini dapat dirumuskan sebagai berikut: Bagaimanakah ketentuan pencatatan nikah menurut UU Nomor 1 Tahun 1974? Bagaimakanah pencatatan nikah menurut hukum Islam?

Dengan memperhatikan rumusan masalah di atas, maka penelitian ini bertujuan untuk mengetahui ketentuan pencatatan nikah menurut UU Nomor 1 Tahun 1974. Selain itu penulis ingin menjelaskan pandangan-pandangan Fuqoha' dan para cendikiawan muslim tentang hukum pencatatan nikah.

\footnotetext{
${ }^{2}$ Dalam kitab-kitab tersebut, hlm-hlm yang harus dipenuhi dalam pernikahan hanyalah lima, yaitu calon suami, calon istri, wali, dua orang saksi dan ijab qobul.
} 


\section{PEMBAHASAN}

\section{Ketentuan Pencatatan Nikah Menurut UU Nomor 1 Tahun 1974}

Nikah dalam konteks syar'i seperti diformulasikan para ulama fiqih, terdapat berbagai rumusan yang satu sama lain berberda-beda. Jangankan antara mazhab fiqih yang berbeda aliran teologisnya, antara mazhab fiqih yang sama aliran teologi dan aliran politiknyapun tidak jarang diwarnai perbedaan. Perhatikan misalnya ta'rif yang diberikan oleh empat mazhab (Hanafiyah, Malikiyah, Syafi'iyah, dan Hanabilah), yang aliran politiknya lazim dianggap sama-sama sunni dan aliran teologisnya sama dalam lingkungan Ahlus Sunnah wal-Jama'ah (Asya'irah/ Maturidiyah), berlainan juga dalam memberikan definisi pernikahan. ${ }^{3}$

Apalagi dihubungkan dengan para fuqoha yang beraliran politik dan teologis berbeda semisal Khawarij, Syi'ah, dan lain sebagainya. Karenanya, hampir mustahil kita bisa mempertemukan berbagai definisi nikah atau perkawinan itu dalam satu rumusan yang benar-benar representatif, apalagi lengkap sempurna memuaskan semua pihak. Perbedaan yang ada itu pada umumnya bahkan keseluruhannya tidak dalam bentuk yang kontradiktif (at-tadladdah) melainkan perbedaan yang bersifat keberagaman (attanawwu').

Mempersoalkan definisi nikah, ada beberapa rumusam sebagai berikut $:^{4}$

1. Menurut sebagian ulama Hanafiyah, nikah adalah akad yang memberikan faidah (mengakibatkan) kepemilikan untuk bersenang-senang secara sadar (sengaja) bagi seorang pria dengan seorang wanita.

2. Menurut sebagian mazhab Maliki, nikah adalah suatu akad yang dilaksanakan dan dimaksudkan untuk meraih kenikmatan (seksual) semata-mata.

3. Mazhab Syafi'iyah merumuskan ta'rif nikah sebagai akad yang menjamin kepemilikan (untuk) bersetubuh dengan menggunakan redaksi (lafal) "inkaah" (انكاح)atau "tazwiij" (تزويج) atau turunan makna dari keduanya

4. Ulama mazhab Hanabilah mendefinisikan nikah sebagai akad yang dilakukan dengan menggunakan kata inkah atau tazwij guna mendapatkan kesenangan (bersenang-senang).

\footnotetext{
${ }^{3}$ Abdur Rahman Al-Jazairi, Al-Fiqh 'ala al-Madzahib al-Arba'ah, Beirut, Dar Fikr, 2010, Jilid 4. $2-3$

${ }^{4}$ Ibid, Jilid 4. $2-3$.
} 
Adapun Rukun atau pilar pernikahan ada lima, ${ }^{5}$ yaitu : Isteri, suami, wali, dua orang saksi, dan shighat. Tidak ada persyaratan pencatatan nikah di dalam kitab-kitab klasik, namun di dalam undang-undang Republik Indonesia Nomor 1 tahun 1974 dijelaskan beberapa hal yang berhubungan dengan pernikahan. Pada bab satu dijelaskan mengenai dasar perkawinan. Pasal 2 menjelaskan tentang sahnya pernikahan harus dilakukan sesuai keyakinan masing-masing dan pasal kedua menyatakan bahwa tiap-tiap perkawinan harus dicatat. Berikut, peneliti kutip secaca lengkap.

\section{Pasal 2}

a. Perkawinan adalah sah, apabila dilakukan menurut hukum masing-masing agamanya dan kepercayaannya itu.

b. Tiap-tiap perkawinan dicatat menurut peraturan perundang-undangan yang berlaku.

Memperhatikan rumusan pada 2 ayat tersebut, memungkinkan multi tafsir; Apakah sahnya perkawinan ditentukan oleh terpenuhinya hukum agama dan kepercayaan saja sebagaimana bunyi ayat (1) Sedangkan pencatatan perkawinan sebagaimana diatur dalam ayat (2) hanya bersifat administratif. Atau apakah kedua ayat tersebut harus dipahami dalam satu kaitan yang tak terpisah. Artinya kesahan perkawinan diukur dari terpenuhinya aturan agama dan peraturan perundang-undangan. ${ }^{6}$

Pencatatan nikah, meski tidak merupakan rukun nikah, dianggap penting untuk pembuktian. Menurut Anderson, pada kebanyakan aturan hukum Islam kontemporer terdapat ketentuan umum bahwa semua akad nikah harus didaftarakan, dan setiap perkawinan yang tidak terdaftar tidak diakui keabsahannya oleh pengadilan. ${ }^{7}$ Tidak diakui keabsahannya oleh pengadilan tidak identik dengan tidak sah menurut hukum agama.

Tanpa mengurangi penghargaan kepada pembentuk UU Perkawinan, kurang tegasnya ketentuan sah-tidaknya perkawinan tanpa pencatatan, sehingga menimbulkan peluang bagi penafsiran yang berbeda-beda, mengurangi wibawa UU Perkawinan itu sendiri. Sebagai suatu perbandingan tentang kedudukan pencatatan nikah, dapat dilihat

\footnotetext{
${ }^{5}$ Muhammad Bin Umar Bin Ali Nawawi al-Jawi, tt. Nihayatuh az-Zain Fi Irsyadi al-Mubtadi'in, Surabaya: al-Hidayah, 300.

${ }^{6}$ Itsnaatul Lathifah, Pencatatan Perkawinan: Melacak Akar Budaya Hukum Dan Respon Masyarakat Indonesia Terhadap Pencatatan Perkawinan, Al-Mazaahib Jurnal Perbandingan Hukum, Vol 3, No 1 (2015), 48.

${ }^{7}$ Anderson, J.N.D, Hukum Islam di Dunia Modern (Islamic Modern Word), Terjemah oleh Machnun Husein. Yogyakarta: Tiara Wacana, 2012, cet. Ke 1. 58.
} 
ketentuan yang berlaku di Malaysia. Di sana, suatu perkawinan (Islam) yang dilangsungkan tanpa memenuhi ketentuan administrasi (pencatatan nikah) tetapi memenuhi ketentuan hukum agama, tetap dianggap sah, walaupun kepada yang bersangkutan dikenakan hukuman berdasarkan ketentuan yang berlaku. ${ }^{8}$ Jika keharusan mencatatakan perkawinaan dianggap sebagai campur tangan negara dalam rangka mewujudkan ketertiban, maka kekurang-tegasan perumusan ini sendiri memberikan peluang bagi penafsiran yang beragama.

Dari perbedaan pendapat tentang kedudukan pencatatan bagi suatu perkawinan menurut UU Perkawinan, KHI tampaknya cenderung pada ketentuan sahnya pernikahan diukur dari dipenuhinya aturan hukum Islam. Sedangkan pencatatan nikah untuk kepentingan administratif dan agar terjamin ketertiban masyarakat Islam sendiri. Hal ini bisa dilihat dari pasal-pasal dalam KHI sebagai berikut:

\section{Pasal 4}

Perkawinan adalah sah, apabila dilakukan menurut hukum Islam sesuai dengan pasal 2 ayat (1) Undang-Undang Nomor 1 tahun 1974 tentang Perkawinan.

\section{Pasal 5}

a. Agar terjamin ketertiban perkawinan bagi masyarakat Islam setiap perkawinan harus dicatat.

b. Pencatatan perkawinan tersebut pada ayat (1) dilakukan oleh Pegawai Pencatat Nikah sebagaimana yang diatur dalam Undang-Undang Nomor 22 tahun 1946 jo. Undang-Undang Nomor 32 tahun 1954

\section{Pasal 6}

a. Untuk memenuhi ketentuan dalam pasal 5, setiap perkawinan harus dilangsungkan di hadapan dan di bawah pengawasan Pegawai Pencatat nikah.

b. Perkawinan yang dilakukan di luar pengawasan Pegawai Pencatat Nikah tidak mempunyai kekuatan hukum.

Ibrahim Hosen menganggap sahnya pernikahan ditentukan oleh hukum agama masing-masing. Menurut beliau, pencatatan nikah adalah masalah sosial. Ali Yafie berpendapat, menikah dengan pencatatan adalah konsekwensi hidup bernegara. Menurut Mohammad Assegaf, pernikahan melalui KUA (dicatatkan) jelas lebih baik, tetapi

${ }^{8}$ Lili Rasyidi, Hukum Perkawinan dan Perceraian di Malaysia dan Indonesia. Bandung: Remaja Rosdakarya, 2011, cet.1. 41. 
keabsahan perkawinan semata-mata ditentukan oleh Tuhan. Menurut Busthtanul Arifin, perkawinan yang sah adalah perkawinan yang dilangsungkan menurut hukum agama, sedangkan pencatatan itu masalah administrasi. Akan tetapi ia menekankan penting campur tangan negara melalui pencatatan perkawinan.

Yahya Harahap berpendapat bahwa perkawinan di bawah tangan (memenuhi ketentuan hukum agama saja) adalah tidak sah menurut undang-undang maupun menurut hukum Islam. ${ }^{9}$ Pendapat senada dikemukakan oleh Abdul Gani Abdullah yang menyatakan bahwa perkawinan baru dikatakan sebagai perbuatan hukum apabila telah memenuhi unsur tata cata agama dan tata cata pencatatan nikah. Unsur pertama berfungsi sebagai pertanda sah dan unsur kedua berfungsi sebagai pertanda perbuatan hukum sehingga berakibat hukum. ${ }^{10}$ Perkawinan tanpa pencatatan baru memperoleh tanda sah dan belum memperoleh tanda perbuatan hukum sehinga belum memperoleh akibat hukum.

Perkawinan yang tidak dicatat di KUA dikenal dengan pernikahan sirri atau perkawinan diam-diam/rahasia merupakan perkawinan di bawah tangan. Artinya perkawinan yang hanya memenuhi ketentuan agama namun tidak dicatat atau dilakukan di hadapan Pegawau Pencatat Nikah sebagaimana diperintahkan oleh UU Perkawinan Nomor 1 tahun 1974. Istilah perkawinan dibawah tangan muncul setelah diundangkannya UU Perkawinan Nomor 1 tahun 1974. Perkawinan sirri atau perkawinan di bawah tangan, walaupun secara materiil memenuhi rukun dan syarat perkawinan menurut syari'at Islam, tetapi karena tidak dilaksanakan/dicatat oleh PPN, maka tidak mempunyai kekuatan hukum. ${ }^{11}$

Sahnya perkawinan dalam Undang-Undang Nomor 1 tahun 1974 tentang Perkawinan, diatur dalam pasal 2 yang menyatakan:

(1) Perkawinan adalah sah, apabila dilakukan menurut hukum masing-masing agamanya dan kepercayaannya itu.

(2) Tiap-tiap perkawinan dicatat menurut peraturan perundang-undangan yang berlaku.

Dalam penjelasan Pasal 2 UU Perkawinan disebutkan bahwa dengan perumusan Pasal 2 ayat (1) ini, tidak ada perkawinan di luar hukum masing-masing agamanya dan kepercayaannya

9 Jazuni, Hukum Islam di Indonesia: Pradilan Agama, Kompilasi Hukum Islam dan Penerapannya, Jakarta, Citra Aditya Bakti, 2005, 129-130

10 Jazuni, Hukum Islam di Indonesia: Pradilan Agama, Kompilasi Hukum Islam dan Penerapannya, Jakarta, Citra Aditya Bakti, 2005, 131.

11 Armansyah, Perkawinan Sirri Dalam Perspektif Hukum Islam Dan Undang-Undang Nomor 1 Tahun 1974 Tentang Perkawinan, Sangaji: Jurnal Pemikiran Syariah Dan Hukum 1 (2), 2017, 200. Https://Doi.Org/Https://Doi.Org/10.52266/Sangaji.V1i2.202. 
itu, sesuai dengan UUD 1945. Adapun yang dimaksud dengan hukum masing-masing agamanya yang berlaku itu termasuk ketentuan peraturan perundang-undangan yang berlaku bagi golongan agamnya dan kepercayaannya itu sepanjang tidak bertentangan atau tidak ditentukan lain dalam Undang-Undang ini.

Kata "kepercayaan" dalam pasal 2 ayat (1) UU Perkawinan dan dalam pasal 29 UUD 1945, menurut pendapat yang lebih kuat, adalah kepercayaan agama. Ada dua pendapat tentang kesahan perkawinan menurut UU Perkawinan. Pendapat pertama mengatakan sudah sah apabila dilakukan menurut hukum masing-masing agama dan kepercayaan. Pendapat kedua mengatakan: agar menjadi sah, perkawinan selain harus dilakukan menurut hukum masing-masing agama dan kepercayaan, juga harus dicatat oleh Pegawai Pencatat Nikah. Persoalan yang diperslisihkan kedua pendapat tersebut adalah kedudukan pencatatan. Sedangkan mengenai hukum agama dan kepercayaan (agama), kedua pendapat tersebut sepakat bahwa perkawinan harus dilaksanakan menurut hukum masing-masing agama dan kepercayaan.

\section{Pencatatan Nikah Menurut Hukum Islam}

Berkaitan dengan pencatatan perkawinan, pada awalnya hukum Islam tidak secara konkret mengaturnya. Pada masa Rasulullah SAW. maupun sahabat belum dikenal adanya pencatatan pernikahan. Waktu itu perkawinan sah apabila telah memenuhi rukun dan syaratsyaratnya. Untuk diketahui masyarakat, pernikahan yang telah dilangsungkan hendaknya dii'lankan, diumumkan kepada khalayak luas, antara lain melalui media walimatul 'ursy. Rasulullah SAW bersabda:

$$
\text { أعلنوالنكاح (رواه احمد). }
$$

“Umumkan pernikahan itu”. (HR. Ahmad).

Dalam hadits lain beliau bersabda:

$$
\text { اولم ولوبشاة (رواه مسلم). }
$$

“Adakan walimah (untuk pernikahan) walau hanya dengan menyembelih seekor kambing”. (HR. Muslim).

${ }^{12}$ Al-Imam Ahmad Bin Hanbal Abi Abdillah asy-Syaibani Musnad al-Imam Ahmad Bin Hanbal. Mesir, Dar Ihya' al-Turats al-Arabi, 2011, J. 4. 571.

${ }^{13}$ Al-Imam Abi al-Husain Muslim al-Naisaburi, Shahih Muslim. Beirut: Dar al-Fikr, 2004, J.9. h.193. Lihat juga dalam Muhammad Bin Idris As-Syafi'i, Musnad Asy-Syaf'i, Beirut: Dar al-Fikr, 2010, J.3. 80. 
Dalam masyarakat kesukuan yang kecil dan tertutup seperti Hijaz dahulu, dengan pesta memotong hewan memang sudah cukup sebagai pengumuman resmi. Akan tetapi dalam masyarakat yang kompleks dan penuh dengan formalitas seperti zaman sekarang, pesta dengan memotong seekor kambing saja tidak cukup melainkan harus didokumentasikan secara resmi pada kantor yang bertugas mengurus hal itu. Keharusan pencatatan nikah seharusnya dipahami sebagai bentuk baru dan resmi dari perintah Nabi Muhammad SAW agar mengumumkan atau mengi'lankan nikah meskipun dengan memotong seekor kambing. Karena itu, mungkin kewajiban pencatatan nikah ini dapat dipikirkan untuk menjadi tambahan rukun nikah dalam kitab fiqih baru nanti. ${ }^{14}$

Berikut akan dikemukakan pendapat beberapa ulama/ pakar hukum Islam dan kaidah fiqhiyyah berkaiatan dengan pencatatan nikah:

1. DR. Wahbah az-Zuhaili

Berkenaan dengan pencatatan nikah, beliau melontarkan sebuah kaidah fiqih sebagai berikut:

$$
\text { ومن القاعدة الشرعية وهي ان لولي الامران يأمربالمباح بما يراه من المصلحة العامة ومتى امر به } 15
$$

"Diantara kaidah Syar'iyyah adalah bahwa penguasa/pemerintah diperkenankan memerintahkan sesuatu yang mubah sesuai dengan pertimbangan maslahat yang dilihatnya. Jika pemerintah/penguasa sudah memerintahkannya, maka wajib dipatuhi”.

Jika untuk tujuan kemaslahan rakyat, negara diberi wewenang untuk membuat regulasi apapun asalkan tidak menabrak ketentuan syari'at. Bahkan negara berhak mewajibkan perkara yang hukum asalnya mubah seperti dalam kaidah di atas. Segala kebijakan/aturan yang dibuat pemerintah seharusnya mengacu kepada kemaslahatan masyarakat. Sebagaimana kaidah fiqh:

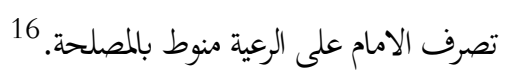

"Kebijakan/aturan pemimpin yang dikenakan atas rakyatnya harus diorientasikan untuk kemaslahatan mereka". Pelajar, 2008, 180-181.

${ }^{14}$ M. Atho Mudzhar, Pendekatan Studi Islam dalam teori dan Praktek, Yogyakarta: Pustaka

${ }^{15}$ Wahbah az-Zuhaili, al-Fiqhu al-Islami wa Adillatuhu, Beirut, Dar Fikr, 2014, Juz VIII. 128. 
2. DR. Ahmad as-Sarbahi

DR. Ahmad al-Sarbahi menyampaikan pendapat yang seirama dengan kaidah yang disampaikan DR. Wahbah az-Zuhaili di atas:

$$
\begin{aligned}
& \text { مادام ولي الأمر قد قصد من وراء ذلك مصلحة المجتمع كان من الواجب على الناس ان يطيعوامره وان يسجلوا } \\
& \text { عقود زواجهم حتى لا تنشؤالعاقبة ولايكون هناك بجال للخداع والاحتيال . }
\end{aligned}
$$

"Selama penguasa dalam menetapkan pencatatan nikah bermaksud merealisasikan mashlahah bagi masyarakat, maka wajib hukumnya bagi masyarakat itu untuk menaati perintahnya dan mencatatkan akad perkawinannya agar tidak timbul akibat negatif serta selamat dari upaya tipu daya dan pengkhianatan."

Berdasarkan pendapat kedua ulama kontemporer tersebut di atas, dapat dipertimbangan penggunaan dalil maslahah mursalah sebagai dasar hukum hukum pencatatan nikah. Pada dasarnya, produk fiqh (hukum Islam) digali dari al-Qur'an dan Sunnah Nabi. Namun ketika ada masalah yang tidak disinggung secara sharih (jelas) di dalamnya, maka untuk menetapkan putusan hukum, bisa digunakan metodologi lain, seperti kemaslahatan umat (Public interest) dan adat kebiasaan ( 'Urf). Pertimbangan maslahah tidak hanya mengakibatkan hukum tertentu berubah, tapi juga dapat melahirkan hukum baru, terutama pada hal-hal yang sebelumnya memang tidak dijumpai ketentuan hukumnya dalam nash. Masuk dalam ranah ini adalah persoalan pencatatan nikah. ${ }^{18}$

Dalam kajian ushul fiqih, salah satu dalil yang dipengangi dalam rangka menelurkan hukum adalah maslahah mursalah. Dalil ini dipedomani oleh Imam Malik sebagai salah satu sumber hukum (fiqh) Islam. Beliau menggunakan dalil ini hanya dalam peristiwa/persoalan hukum yang mempunyai korelasi dengan al-maslahah adl-dlariyyah al-kulliyah Maslahah mursalah, yakni kemaslahatan pokok dan asasi yang kehadirannya mesti diapreasi secara jelas dan qoth'i. ${ }^{19}$

Maslahah mursalah dalam terminologi ushuliyyun (pakar ushul fiqh) adalah sebuah maslahah / kebaikan yang tidak disyari'atkan hukum untuk merealisasikannya, dan tidak ada dalil yang menunjukkan diperhitungkan atau diabaikannya maslahah tersebut. ${ }^{20}$ Penerapan dalil ini semata-mata karena pertimbangan kebaikan/maslahah yang mengitari masyarakat sebagai

${ }^{17}$ Ahmad as-Sarbahi, Yas'alunaka fi ad-Din wa al-Hayah, Beirut: Dar al-Jail, 2009, J.III, 126

18 "Pencatatan Nikah: Fiqh Vis A Vis Negara". Buletin Tanwirul Afkar. Edisi 328. Desember 2006.

19 Abu Yazid, Aspek-asoek Penelitian Hukum: Hukum Islam - Hukum Barat, Yogyakarta: Pustaka Pelajar, 2010, cet. I, 50

${ }^{20}$ Abdu al-Wahab Khollaf, Ilmu Ushul al-Fiqh, Kairo: Dar al-Qolam, 2012, cet XII, h. 84. 
subyek hukum. Al-Khawarizmi memberi batasan maslahah dengan memelihara tujuan syara' dengan menolak/menghindarkan kerusakan dari makhluk. ${ }^{21}$

Sebutan lain bagi maslahah mursalah ialah istishlah, yaitu menetapkan hukum dalam hal-hal yang sama sekali tidak disebutkan dalam nash, dengan pertimbangan untuk kepentingan hidup manusia, yang bersendikan pada asas menarik manfaat dan menghindarkan madarat. Kata 'maslahat' berarti kepentingan hidup manusia, dan kata 'mursalah' berarti lepas dari ketentuan dalil khusus yang membenarkannya atau membatalkannya. Misalnya mengenai mengaharuskan agar pernikahan dicatat, tidak ada satu nash pun yang membenarkan dan membatalkannya. Pencatatan bertujuan memperoleh kepastian hukum atas terjadinya perkawinan, yang akan dipergunakan oleh negara untuk melindungi hak masing-masing suami isteri. Tanpa pencatatan, negara tidak mempunyai dokumen otentik atas terjadinya perkawinan. $^{22}$

3. Majelis Ulama Indonesia

MUI dalam fatwanya menetapkan wajibnya mencatatkan pernikahan pada instansi yang berwenang, sebagai langkah preventif untuk menolak dampak negatif / madlarrat (saddu lidz-dzarii'ah). ${ }^{23}$ Di antara dasar hukum fatwa ini adalah :

a. Hadits Nabi s.a.w.:

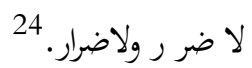

“Tidak boleh ada bahaya dan tidak boleh mendatangkan bahaya pada orang lain”.

b. Hadits Nabi s.a.w.:

$$
\text { أعلنواهذالنكاح واجعلوه في المساجد واضربوا عليه بالدفوف (رواه الترمذي). }
$$

"Umumkan pernikahan ini dan selenggarakan di masjid serta pukullah rebana untuk merayakannya".(HR. At-Turmudzi)

${ }^{21}$ Departemen Agama Prop. Jawa Timur, 2007. "Keputusan Fatwa MUI tahun 2005 tentang Kriteria Maslahah”. Fatwa Munas VII Majelis Ulama Indonesia, 50.

22 Ahmad Azhar Basyir, Pokok-Pokok Ijtihad Dalam Hukum Islam, Ijtihad dalam Sorotan, Bandung: Mizan, 2016, Cet.I, 49.

23 'Keputusan Komisi B Ijima' Ulama Komisi Fatwa se-Indonesia II tahun 2006 tentang Nikah di Bawah Tangan, Kementerian Agama Provinsi Jawa Timur, Himpunan Peraturan Perundang-undangan Perkawinan, 2010, 628.

${ }^{24}$ Abu Isa Muhammad Bin Isa Bin Saurah, Sunan at-Turmudzi. Beirut: Dar al-Fikr, 2010, Juz VII. 347 
c. Hadits Nabi:

$$
\text { اولم ولوبشاة (رواه الشافعي) }
$$

“Adakanlah walimah walaupun hanya dengan memotong seekor kambing”. (HR. as-Syafi'i)

d. Firman Allah dalam surat an-Nisa' ayat 59:

$$
\text { ياايها الذين امنوالطيعوالله واطيعوالرسول واولى الامرمنكم }
$$

"Wahai orang yang beriman taatilah Allah dan taatilah Rasul-Nya sdan ulil amri di antara kalian”.

e. Hadits Nabi s.a.w. :

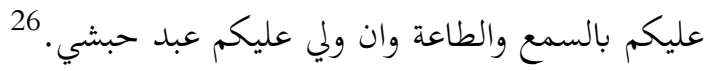

"Kalian wajib mendengar dan taat (kepada pemimpin/penguasa) meskipun yang menjadi penguasamu itu seorang budak Habsyi”.

f. Sayyid Sabiq

Berkaitan dengan urgensitasnya akta nikah bagi pernikahan, Sayyid Sabiq memberi komentar sebagai berikut:

$$
\text { لايجوزسماع الدعوى من احد الزوجين اوغيره الااذاكانت ثابتة باوراق رسمية. } 27
$$

“Tidak boleh mendengarkan (tidak diterima) gugatan salah seorang suami isteri atau pihak lain kecuali apabila dibuktikan dengan dokumen resmi"..

Untuk melindungi pasangan suami isteri yang telah diikat oleh sebuah ikatan pernikahan dari kemungkinan salah satu pihak menzholimi pihak yang lain atau melakukan hal-hal yang dapat merugikan pihak lainnya, maka pemerintah berhak turut campur membuat regulasi yang bersifat mengikat yang menjamin terpeliharanya hak masing-masing. Sehingga bangunan rumah tangga yang dibangun benar-benar dapat mengapai cita-cita mulianya, yaitu terbentuknya keluarga yang bahagia lahir batin dalam suasana mawaddah (cinta kasih) dan

\footnotetext{
${ }^{25}$ Muhammad Bin Idris As-Syafi'i, Musnad Asy-Syaf'i, Beirut: Dar al-Fikr, 2010, J.3. 80

${ }^{26}$ Jalaluddin as-Suyuti. Jami'u al-Kabir, Beirut: Dar al-Fikr, 2010, 14572

${ }^{27}$ Sayyid Sabiq, Fiqhu al-Sunnah, Beirut: Dar al-Fikr, 2013, J. II. 59
} 
rahmah (kasih sayang). Seperti dikemukakan oleh Sayyidina Utsman Bin Affan:

$$
\text { يزع الله بالسلطان ما لا يزع بالقران. }
$$

"Allah mengatur/menyelesaikan dengan alat kekuasaan terhadap sesuatu urusan yang Ia (Allah) tidak menyelesaikannya dengan al-Qur'an”.

Pencatatan nikah seperti diatur dalam Undang-Undang Nomor 1 tahun 1974 pasal 2 ayat (2), dan ditegaskan dalam Kompilasi Hukum Islam pasal 5, secara substantif tidak bertentangan dengan hukum Islam. Bahkan selaras dengan tujuan disyari’tkannya nikah sendiri. Dengan pencatatan nikah, di samping akan terwujud ketertiban perkawinan masyarakat, juga bagi masing-masing laki-laki dan perempuan yang sudah terikat pernikahan memiliki bukti otentik sebagai pasangan suami isteri. Dengan demikian, pernikahannya memiliki kepastian hukum. Sebuah kaidah fiqh menyatakan:

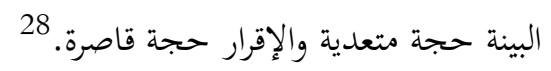

"Bayyinah (saksi/bukti) merupakan hujjah yang berdampak luas dan kuat, sedangkan pengakuan hanya merupakan hujjah yang terbatas".

Bayyinah dalam konteks nikah di sini dapat diartikan buku nikah (kutipan akta nikah). Pencatatan nikah sangat penting dan diwajibkan oleh negara, namun hal tersebut tidak lantas membatalkan pernikahan yang tidak dicatatkan. Hal ini dapat dilihat dari beberapa pendapat pakar fiqih bahwa dalam pernikahan ada syarat syar'I da nada syarat (tausiqi).

Menurut Syekh Jaad al-Haq Ali Jaad al-Haq, perkawinan yang dilaksanakan dengan memenuhi ketentuan syarat-syarat yang diatur dalam syari'at, hukumnya sah. Sedangkan pencatatan merupakan unsur tambahan dalam akad nikah. Peraturan tambahan tausiqi bertujuan agar pernikahan menjadi tertib dan tidak liar. Oleh karena itu, dilakukan pencatatan dan pemberian kutipan akta nikah (buku nikah) yang dikeluarkan oleh pihak yang berwenang. Peraturan tambahan (tausiqi) tidak mengurangi sahnya perkawinan.

${ }^{28}$ Ibrahim Mahmud Muhammad Hariri. Al-Madkhol Ilaa Qawa'id al-Fiqhiyyah al-Kulliyah, Damaskus: Dar al-Fikr, 2009, 160. 
Wahbah Az-Zuhaili membagi syarat pernikahan menjadi dua bagian. Pertama, syarat syar' $i$, yaitu suatu syarat yang kesahan suatu ibadah atau akad bergantung kepada dipenuhinya syarat tersebut. Kedua, syarat tausiqi, yaitu syarat yang dirumuskan sebagai bukti kebenaran terjadinya peristiwa sebagai usaha antisipasi bila suatu ketika ada pengingkaran. Syarat tausiqi ini tidak menentukan sah-tidaknya suatu akad dari aspek agama. Ia dimaksudkan untuk keperluan tertib administrasi dan kepastian hukum menurut negara.

Berkaitan dengan hukum tidak tercatat, Wahbah az-Zuhaili menyatakan والزواج العرفي غيرالمسجل في المحاكم الشرعية تكون فيه ثابتة ديانية وترتب عليها الأحكام الشرعية من نفقة وثبوت نسب الأولاد وغير ذلك.

"Perkawinan urfi yang tidak dicatatkan pada mahkamah syar'iyyah, perkawinannya tetap diakui/sah secara agama dan berkonsekwensi ada hukumhukum syar'iyyah yang menyertainya, seperti hak nafkah, diakuinya nasab anak dan lain sebaginya".

Pendapat yang lain juga disampaikan oleh Ahmad as-Sarbahi yang menegaskan bahwa sahnya pernikahan tidak menunggu pencatatan, yang terpenting syarat dan rukunnya terpenuhi. Syekh Ahmad as-Sarbahi mengatakan:

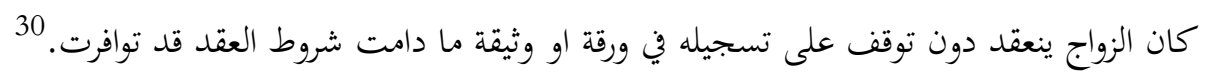

"Perkawinan itu jadi (sah) tanpa menunggu dicatatkannya dalam suatusurat atau dokumen selama perkawinan tersebutmemenuhi syarat-syarat akad."

${ }^{29}$ Wahbah az-Zuahili, al-Fiqhu al-Islami wa Adillatuhu, Beirut: Dar al-Fikr, 2014, J. 4, 22.

${ }^{30}$ Ahmad as-Sarbahi, Yas'alunaka wa fi ad-Din al-Hayah, Beirut: Dar al-Jail, 2009, J.III, 126. 


\section{KESIMPULAN}

Dari pembahasan di atas, dapat ditarik kesimpulan bahwa Undang-Undang Republik Indonesia Nomor 1 tahun 1974 pada Pasal 2 menjelaskan bahwa sahnya pernikahan harus dilakukan sesuai keyakinan masing-masing dan tiap-tiap perkawinan harus dicatat sesuai peraturan pemerintah. Terkait pencatatn pernikahan, para Ulama menjelaskan bahwa kewajiban pencatatan pernikahan yang ditetapkan oleh pemerintah tidak bertentangan dengan syariat Islam karena sesuai dengan disyariatkannya pernikahan. Dengan pencatatan nikah, di samping akan terwujud ketertiban perkawinan masyarakat, juga bagi masing-masing laki-laki dan perempuan yang sudah terikat pernikahan memiliki bukti otentik sebagai pasangan suami isteri. Dengan demikian, pernikahannya memiliki kepastian hukum. Namun jika ada pernikahan yang tidak dicatatkan, maka secara agama tetap sah selama syarat dan rukunnya terpenuhi.

\section{DAFTAR PUSTAKA}

Abi Abdillah asy-Syaibani, Al-Imam Ahmad Bin Hanbal Musnad al-Imam Ahmad Bin Hanbal, Mesir, Dar Ihya' al-Turats al-Arabi, 2011.

Abu Isa Muhammad Bin Isa Bin Saurah, Sunan at-Turmudzi. Beirut: Dar al-Fikr, 2010. Ali, Zainuddin, Hukum Perdata Islam Di Indonesia, Grafika, Jakarta, 2007

Al-Jazairi, Abdur Rahman, Al-Fiqh 'ala al-Madzahib al-Arba'ah, Beirut, Dar Fikr, 2010.

Anderson, J.N.D, Hukum Islam di Dunia Modern (Islamic Modern Word), Terjemah oleh Machnun Husein. Yogyakarta: Tiara Wacana, 2012.

Armansyah, Perkawinan Sirri Dalam Perspektif Hukum Islam Dan Undang-Undang Nomor 1 Tahun 1974 Tentang Perkawinan, Sangaji: Jurnal Pemikiran Syariah Dan Hukum 1 (2), 2017, Https://Doi.Org/Https://Doi.Org/10.52266/Sangaji.V1i2.202.

As-Sarbahi, Ahmad, Yas'alunaka fi ad-Din wa al-Hayah, Beirut: Dar al-Jail, 2009. As-Suyuti, Jalaluddin. Jami'u al-Kabir. Beirut: Dar al-Fikr, 2010

As-Syafi'i, Muhammad Bin Idris, Musnad asy-Syafi'i, Beirut : Dar al-Fikr, 2010. Azhar Basyir, Ahmad, Pokok-Pokok Ijtihad Dalam Hukum Islam, Ijtihad dalam Sorotan, Bandung: Mizan, 2016.

Az-Zuhaili, Wahbah, al-Fighu al-Islami wa Adillatuhu, Beirut, Dar Fikr, 2014 
Departemen Agama Prop. Jawa Timur, Keputusan Fatwa MUI tahun 2005 tentang Kriteria Maslahah, Fatwa Munas VII Majelis Ulama Indonesia, 2007.

Jazuni, Hukum Islam di Indonesia: Pradilan Agama, Kompilasi Hukum Islam dan Penerapannya, Jakarta, Citra Aditya Bakti, 2005.

Jamaluddin Athiyyah, Nahwa Taf'il Maqashid asy'Syar'iyyah. Damaskus: Dar al-Fikr, 2001.

Keputusan Komisi B Ijima’ Ulama Komisi Fatwa se-Indonesia II tahun 2006 tentang Nikah di Bawah Tangan, Kementerian Agama Provinsi Jawa Timur, Himpunan Peraturan Perundang-undangan Perkawinan, 2010.

Khollaf, Abdul Wahab, Ilmu Ushul al-Fiqh, Kairo: Dar al-Qolam, 2012.

Lathifah, Itsnaatul, Pencatatan Perkawinan: Melacak Akar Budaya Hukum Dan Respon Masyarakat Indonesia Terhadap Pencatatan Perkawinan, Al-Mazaahib Jurnal Perbandingan Hukum.

Mudzhar, M. Atho, Pendekatan Studi Islam dalam teori dan Praktek. Yogyakarta: Pustaka Pelajar, 2008.

Muhammad Bin Umar Bin Ali Nawawi al-Jawi, tt. Nihayatuh az-Zain Fi Irsyadi alMubtadi'in, Surabaya: al-Hidayah,

Muhammad Hariri, Ibrahim Mahmud. Al-Madkhol Ilaa Qawa'id al-Fiqhiyyah alKulliyah, Damaskus: Dar al-Fikr, 2009.

Muslim al-Naisaburi, Al-Imam Abi al-Husain, Shahih Muslim. Beirut: Dar al-Fikr, 2004.

Pencatatan Nikah: Fiqh Vis A Vis Negara". Buletin Tanwirul Afkar. Edisi 328. Desember 2006.

Rasyidi, Lili, Hukum Perkawinan dan Perceraian di malaysia dan Indonesia, Bandung: Remaja Rosdakarya, 2011.

Sabiq, Sayyid, Fiqhu al-Sunnah, Beirut: Dar al-Fikr, 2013.

Yazid, Abu, Aspek-asoek Penelitian Hukum: Hukum Islam - Hukum Barat, Yogyakarta: Pustaka Pelajar, 2010. 